\title{
Kadar Protein Kasar dan Serat Kasar Jagung Kuning Giling pada Difermentasi dengan EM-4 Pada Level yang Berbeda
}

\author{
Santi \\ Program Studi Peternakan, Universitas Al Asyariah Mandar \\ santipeternakan@gmail.com
}

\begin{abstract}
Abstrak
Rendahnya kadar protein jagung dan haerga mahal. Tujuan penelitian ini adalah untuk meningkatktan kadar protein kasar dan menurunkan serat kasar jagung kuning giling yang difermentasi EM-4. Penelitian ini dilaksanakan dua tahap yaitu; tahap pertama fermentasi jagung kuning di Laboratorium Industri Pengolahan Pakan Fakultas Peternakan Universitas Hasanuddin Makassar, dan tahap kedua yaitu analisis proksimat di Laboratorium Kimia Makanan Ternak Fakultas Peternakan Universitas Hasanuddin, Makassar. Menggunakan metode rancangan acak lengkap (RAL) yang terdiri dari 5 perlakuan dan 4 ulangan, dengan susunan perlakuan adalah $\mathrm{P}_{0}$ ( $2 \mathrm{~kg}$ jagung kuning giling), $\mathrm{P}_{1}(2 \mathrm{~kg}$ agung kuning giling $+25 \mathrm{cc}$ EM- $4+500 \mathrm{cc}$ air $), \mathrm{P}_{2}(2 \mathrm{~kg}$ agung kuning giling $+1 \%$ urea $+25 \mathrm{cc}$ EM-4 $+500 \mathrm{cc}$ air $), \mathrm{P}_{3}(2 \mathrm{~kg}$ agung kuning giling $+1 \%$ urea $+35 \mathrm{cc}$ EM-4 $+500 \mathrm{cc}$ air $)$, dan $\mathrm{P}_{4}(2 \mathrm{~kg}$ agung kuning giling $+1 \%$ urea + 45 cc EM-4 + 500 cc air). Hasil sidik ragam menunjukkan bahwa fermenjasi jagung kuning giling dengan menggunakan EM-4 berpengaruh sangat nyata $(\mathrm{P}<0.01)$ terhadap kadar proteinkasar dan serat kasar). Disimpulkan bahwa hasil fermentasi yang paling baik pada perlakuan $\mathrm{P}_{3}$ yaitu kadar protein kasar paling tinggi (10.54\%) dan rendahnya serat kasar $(2.44 \%)$.
\end{abstract}

Keywords : EM-4, fermentasi, jagung kuning.

\section{Pendahuluan}

Salah satu masalah dalam usaha peternakan adalah mahalnya biaya pakan yang dapat mencapai 60$80 \%$ dari biaya produksi. Hal ini disebabkan adanya kompetisi penggunaan bahan baku dengan kepentingan manusia yang semakin meningkat, sehingga perlu adanya usaha untuk efesiensi penggunaan pakan.

Penggunaan jagung sebagai pakan ternak unggas terdapat beberapa kendala, yaitu rendahnya kandungan protein kasar dan mahalnya harga. Jagung merupakan salah satu bahan baku pakan sumber energy yang ada di Indonesia.

Salah satu cara untuk mengatasi kendala pada jagung tersebut adalah melakukan fermmentasi dengan menggunakan Efective microorganisms (EM-4). Teknologi fermentasi dapat digunakan untuk meningkatkan nilai gizi bahan tersebut (Pasaribu dkk., 1998). Produk fermentasi bersifat lebih mudah dicerna karena serat lebih rendah dan protein yang lebih tinggi. Tujuan penelitian ini adalah untuk meningkatkan kadar protein kasar dan menurunkan kadar serat kasar.

\section{Metodologi}

Penelitian ini dilaksanakan dua tahap yaitu; tahap pertama fermentasi jagung kuning di Laboratorium Industri Pengolahan Pakan Fakultas Peternakan Universitas Hasanuddin Makassar, dan tahap kedua yaitu analisis proksimat di Laboratorium Kimia Makanan Ternak Fakultas Peternakan Universitas Hasanuddin, Makassar.

Alat yang digunakan yaitu timbangan, ember, lakban, dan kantong plastic. Bahan yang digunakan yaitu jagung kuning giling, EM-4, urea, molasses, dan air.

Penelitian ini menggunakan rancangan acak lengkap (RAL) yang terdiri dari 5 perlakuan dan 4 ulangan, dengan susunan perlakuan sebagai berikut:

Agrovital | Jurnal Ilmu Pertanian Universitas Al Asyariah

$$
\begin{aligned}
\mathrm{P}_{0}= & 2 \mathrm{~kg} \text { jagung kuning giling } \\
\mathrm{P}_{1}= & 2 \mathrm{~kg} \text { agung kuning giling }+25 \mathrm{cc} \text { EM- } 4+500 \\
\mathrm{cc} \text { air } & \\
\mathrm{P}_{2}= & 2 \mathrm{~kg} \text { agung kuning giling }+1 \% \text { urea }+25 \mathrm{cc} \\
& \text { EM- } 4+500 \mathrm{cc} \text { air } \\
\mathrm{P}_{3}= & 2 \mathrm{~kg} \text { agung kuning giling }+1 \% \text { urea }+35 \mathrm{cc} \\
& \text { EM- } 4+500 \mathrm{cc} \text { air } \\
\mathrm{P}_{4}= & 2 \mathrm{~kg} \text { agung kuning giling }+1 \% \text { urea }+45 \mathrm{cc} \\
& \text { EM- } 4+500 \mathrm{cc} \text { air }
\end{aligned}
$$

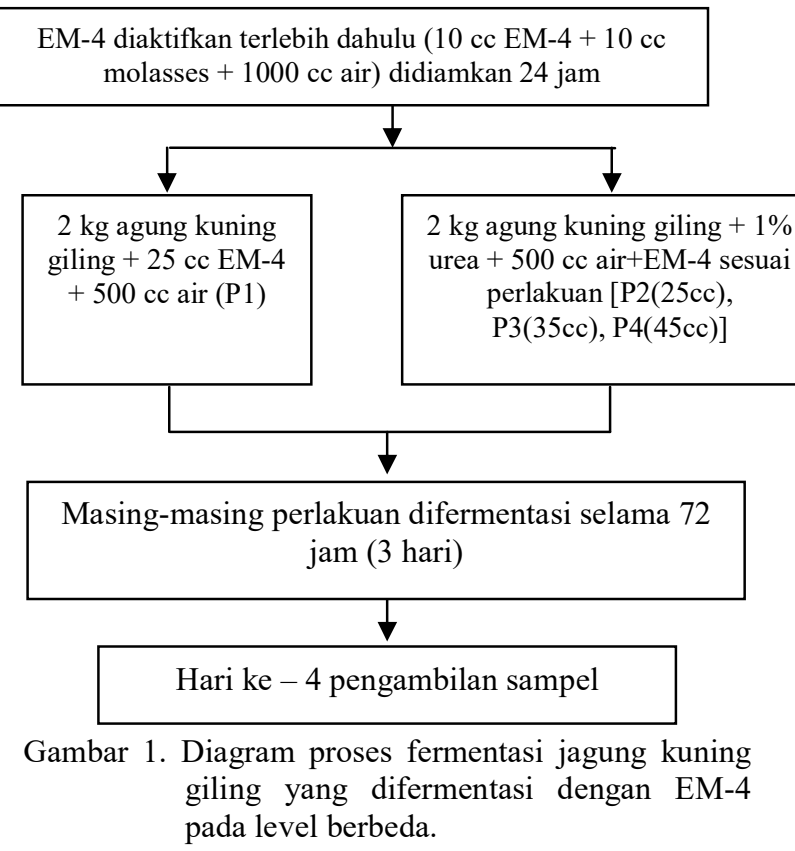

Data yang diperoleh dianalisi denga menggunakan SPSS 13 


\section{Hasil dan Pembahasan}

\section{Kadar Protein Kasar}

Kadar protein kasar jagung kuning yang difermentasi dengan EM-4 pada level yang berberda dapat dilihat pada Tabel 1.

Tabel 1. Kadar Protein Kasar (\%) Jagung Kuning Giling yang Difermentasi dengan EM-4 pada Level yang Berbeda

\begin{tabular}{ccllll}
\hline \multirow{2}{*}{ ulangan } & \multicolumn{5}{c}{ Perlakuan } \\
\cline { 2 - 6 } & $\mathrm{P}_{0}$ & $\mathrm{P}_{1}$ & $\mathrm{P}_{2}$ & $\mathrm{P}_{3}$ & $\mathrm{P}_{4}$ \\
\hline 1 & 7.19 & 7.44 & 10.42 & 9.59 & 10.44 \\
2 & 6.83 & 8.41 & 8.78 & 11.37 & 9.98 \\
3 & 7.03 & 7.73 & 9.49 & 10.67 & 9.68 \\
4 & 7.18 & 7.71 & 10.25 & 10.70 & 9.61 \\
\hline Rata-rata & $7.06^{\mathrm{a}}$ & $7.82^{\mathrm{a}}$ & $9.74^{\mathrm{b}}$ & $10.58^{\mathrm{c}}$ & $9.93^{\mathrm{bc}}$ \\
\hline
\end{tabular}

Keterangan : Huruf Yang Berbbeda pada Superscript Angka Rata-Rata Berbeda Sangat Nyata $(\mathrm{P}<0.01)$.

Berdasarkan sidik ragam jagung kuning giling yang difermentasi dengan EM-4 pada level yang berbeda berpengaruh sangat nyata $(\mathrm{P}<0.01)$ terhadap kadar protein kasar. Berdasarkan table 2 menunjukkkan setiap perlakuan cenderung mengalami peningkatan kadar protein kasar.

Hasil uji Duncan protein kasar menunjukkan bahwa $\mathrm{P}_{0}$ berbeda sangat nyata terhadap $\mathrm{P}_{2}, \mathrm{P}_{3}$ dan $\mathrm{P}_{4} \quad(\mathrm{P}<0.01)$ tetapi tidak berbeda nyata pada $\mathrm{P}_{1}$. Perlakuan $\mathrm{P} 1$ berbeda sangat nyata dengan $\mathrm{P}_{2}, \mathrm{P}_{3}$ dan $\mathrm{P}_{4}(\mathrm{P}<0.01)$. Perlakaun $\mathrm{P}_{2}$ berbeda nyata dengan $\mathrm{P}_{3}(\mathrm{P}<0.05)$ tetapi tidak berbeda nyata dengan $\mathrm{P}_{4}$. Perlakauan $\mathrm{P}_{3}$ tidak berbeda nyata dengan $\mathrm{P}_{4}$.

Protein kasar cenderung meningkat karena populasi awal pada perlakuan $\mathrm{P}_{2}, \mathrm{P}_{3}$, dan $\mathrm{P}_{4}$ mikroorganisme meningkat. Sandi, dkk., (2010) menyatakan tingginya kadar protein pada pakan fermentasi karena sumbansi dari mikroorganisme. Hermanto (2011) protein dari rumput silase mengalami degradasi (proteolisis) baik oleh enzim protease tanaman maupun mikroba menjadi senyawa NPN (non-protein nitrogen) terutama asam amino dan amonia. Selanjutnya Ruswandi (2014) menyatakan meningkatnya jumlah mikroba maka kadar protein kasar pakan fermentasi akan mengalami peningkatan, karena mikroba merupakan sumber protein sel tunggal.

Rendahnya protein kasar pada $\mathrm{P}_{1} \quad(7.82 \%)$ dibandingakan perlakuan $\mathrm{P}_{2}, \mathrm{P}_{3}$ dan $\mathrm{P}_{4}$ disebabkan tidak adanya penambahan urea. Hal ini sesuai dengan pendapat Rosningsih (2011) menyatakan bahwa peningkaian kadar protein kasar akibat fermentasi cukup tinggi. Akan tetapi, sabagian protein kasar tersebut terdiri dari nitrogen (protein) terlarut yang mungkin berasal dari urea yang ditambahkan sebelum proses fermentasi, disamping itu peningkatan protein juga terdiri atas asam amino non essensial dan NPN seperti khitin dan asam nukleat.

Agrovital | Jurnal Ilmu Pertanian Universitas Al Asyariah

\section{Kadar Serat Kasar}

Kadar protein kasar jagung kuning yang difermentasi dengan EM-4 pada level yang berberda dapat dilihat pada Tabel 2.

Tabel 2. Kadar Serat Kasar (\%) Jagung Kuning Giling yang Difermentasi dengan EM-4 pada Level yang Berbeda

\begin{tabular}{ccllll}
\hline \multirow{2}{*}{ ulangan } & \multicolumn{5}{c}{ Perlakuan } \\
\cline { 2 - 6 } & $\mathrm{P}_{0}$ & $\mathrm{P}_{1}$ & $\mathrm{P}_{2}$ & $\mathrm{P}_{3}$ & $\mathrm{P}_{4}$ \\
\hline 1 & 3.15 & 3.38 & 3.86 & 2.28 & 2.62 \\
2 & 2.41 & 3.76 & 3.49 & 2.82 & 2.5 \\
3 & 2.53 & 3.93 & 3.36 & 2.82 & 2.64 \\
4 & 2.79 & 4.66 & 3.25 & 1.87 & 2.64 \\
\hline Rata-rata & $2.72^{\mathrm{ab}}$ & $3.93^{\mathrm{a}}$ & $3.49^{\mathrm{a}}$ & $2.44^{\mathrm{b}}$ & $2.6^{\mathrm{b}}$ \\
\hline Keterangan : & Huruf Yang & Berbbeda & pada Superscript \\
& Angka Rata-Rata Berbeda Sangat Nyata \\
& $(\mathrm{P}<0.01)$.
\end{tabular}

Beradasarkan sidik ragam fermentasi jagung kuning giling yang difermentasi dengan EM-4 pada level yang berbeda berpengaruh sangat nyata $(\mathrm{P}<0.01)$ terhadap kadar serat kasar. Pada Tabel 2 menunjukkan bahwa pada perlakuan $\mathrm{P}_{3}$ dan $\mathrm{P}_{4}$ mengalami penurunan serat kasar, sedangkan pada perlakuan $\mathrm{P}_{1}$ dan $\mathrm{P}_{2}$ mengalami peningkatan.

Hasil uji Duncan menunjukkan bahwa perlakauan $\mathrm{P}_{0}$ tidak berbeda nyata $(\mathrm{P}>0.05)$ dengan $\mathrm{P}_{1}, \mathrm{P}_{2}, \mathrm{P}_{3}$, dan $\mathrm{P}_{4}$. $\mathrm{P}_{1}$ tidak berbeda nyata $(\mathrm{P}>0.05)$ dengan $\mathrm{P}_{2}$, tetapi berbeda sangat nyata $(\mathrm{P}<0.01)$ dengan $\mathrm{P}_{3}$, dan $\mathrm{P}_{4}$. Perlakuan $\mathrm{P}_{2}$, berbeda sangat nyata $(\mathrm{P}<0.01)$ dengan $\mathrm{P}_{3}$, dan $\mathrm{P}_{4}$. Sedangkan $\mathrm{P}_{3}$ tidak berbeda nyata $(\mathrm{P}>0.05)$ dengan $\mathrm{P} 4$.

Peningkata serat pada $\mathrm{P}_{1}$ dan $\mathrm{P}_{2}$ menghasilkan serat kasar yang semakin tinggi. Lebih lanjut dalam proses fermentasi, mikroba cenderung memanfaatkan BETN untuk pertumbuhan mikroba. Mikroba cenderung memanfaatkan BETN yang tersedia dibandingkan serat kasar yang sulit dicerna. Rohmawati, (2015), nilai BETN tergantung pada nilai nutrisi seperti PK, LK, abu, SK, semakin nilai PK, LK, abu, SK semakin tinggi maka nilai BETN semakin rendah. Penurunan kandungan BETN ini bisa terjadi karena dalam proses fermentasi akan terjadi proses degradasi bahan (substrat) oleh mikroba. Menurut Hastuti, dkk (2011) bahwa adanya peningkatan aktivitas mikroba dalam mendegradasi substrat, maka akan mempengaruhi juga pemakaian energi (BETN) yang semakin banyak pula, sehingga dalam aktivitas mikroba yang tinggi dapat menurunkan kandungan BETN

Serat kasar pada $\mathrm{P}_{3}$ dan $\mathrm{P}_{4}$ menunjukkan bahwa mikroorganisme yang ada pada EM-4 mampu menggunakan serat sebagai summber karbon. Hal ini sesuai dengan pendapat Anggraheny dan Umiyasih, (2009), Penurunannya diakibatkan terjadi aktivitas mikroba menghasilkan selulase dan enzim lainnya yang mampu memecah ikatan kompleks serat kasar menjadi lebih sederhana.

Hampir separuh dari hemisellulosa dapat didegradasi. Ada tiga kemungkinan penyebab pemecahan hemisellulosa, yaitu : (1) degradasi oleh enzim-enzim hemisellulase tanaman, (2) degradasi oleh 
enzim hemisellulase bakteri dan (3) hidrolisis oleh asam organik yang dihasilkan selama proses fermentasi (Hidyai, 2014). Mikroba lebih banyak sehingga jumlah populasi mikroba meningkat untuk memecah selulosa dan hemiselulosa oleh enzim yang dihasilkan oleh mikroba bila dibandingkan dengan tanpa bahan tambahan.Enzim yang dihasilkan oleh mikroba tertentu akan merombak selulosa dan hemiselulosa menjadi komponen yang lebih sederhana sehingga secara keseluruhan kadar serat kasar pada perlakuan dengan bahan tambahan silase akan menurun (Riswandi, 2014)

\section{Kesimpulan}

Berdasarkan analisa data sementara maka dapat disimpulkan sebagai yaitu nilai nutrisi yang paling baik pada $\mathrm{P}_{3}$ dengan kadar protein paling tinggi $10.58 \%$ dan serat kasar yang rendah $2.44 \%$.

\section{Daftar Pustaka}

Anggraeny, Y. N., dan U. Umiyasih. 2009. Pengaruh Fermentasi Saccharomyces cerevisiae terhadap Kandungan Nutrisi dan Kecernaan Ampas Pati Aren (Arenga pinnata MERR.). Seminar Nasional Teknologi Peternakan dan Veteriner : 256-262.

Hastuti, D., N. Suliastri, dan B. Iskandar.2011. Pengaruh Perlakuan Teknologi Amofer (Amoniasi Fermentasi) pada Limbah Tongkol Jagung
Sebagai Alternatif Pakan Berkualitas Ternak Ruminansia. Jurnal Mediagro, V. 7 (1) : 55-65.

Hidayat, N., 2014. Karakteristik dan kualitas silase rumput raja menggunakan berbagai sumber dan tingkat penambahan karbohidrat fermentable. Agripet 14 (1) : 42-49.

Hermanto, 2011. Sekilas Agribisnis Peternakan Indonesia. konsep pengembangan peternakan, menuju perbaikan ekonomi rakyat serta meningkatkan gizi generasi mendatang melalui pasokan protein hewani asal peternakan. [9 Juli 2011]

Riswandi, 2014. Kualitas silase eceng gondok (Eichhornia crassipes) dengan penambahan dedak halus dan ubi kayu. Jurnal Peternakan Sriwijaya 3(1): 1-6.

Rohmawati, D., I. H. Djunaidi, \& E. Widodo. 2015. Nilai nutrisi tepung kulit ari kedelai dengan level inokulum ragi tape dan waktu inkubasi berbeda. J. Ternak Tropika 16(1): 30-33.

Rosningsih, S. 2011. Evaluasi nilai nutrisi onggok hasil fermentasi sebagai bahan pakan ternak ungags. Jurnal Agrisains 2 (1)

Sandi, S., F. B. Sudarman, K. G. Wirawan, \& D. Mangundjaja, 2010. Kualitas nutrisi silase bahan baku singkong yang diberi enzim cairan rumen sapi dan Leuconostoc mesenteroides. Media Peternakan Vol 33(1). 